\title{
Protein intake and urinary albumin excretion rates in the EURODIAB IDDM Complications Study
}

\author{
M. Toeller ${ }^{1}$, A . B uyken ${ }^{1}$, G. H eitkamp ${ }^{1}$, S. B rämswig ${ }^{1}$, J . Mann ${ }^{2}$, R . M ilne ${ }^{2}$, F. A . G ries ${ }^{1}$, H . Keen ${ }^{3}$ and the \\ E U R O D IA B ID D M Complications Study G roup* \\ ${ }^{1}$ Diabetes Research Institute at the Heinrich-Heine-University, Clinical Department, Düsseldorf, Germany \\ ${ }^{2}$ University of Otago, Department of Nutrition, Dunedin, New Zealand \\ ${ }^{3}$ Unit for Metabolic Medicine, United Medical and Dental Schools, Guy's Hospital Campus, London, UK
}

Summary For people with insulin-dependent diabetes mellitus (IDDM) renal disease represents a lifethreatening and costly complication. The EURODIAB IDDM Complications Study, a cross-sectional, clinic-based study, was designed to determine the prevalence of renal complications and putative risk factors in stratified samples of European individuals with IDDM. The present study examined the relationship between dietary protein intake and urinary albumin excretion rate (AER). Food intake was assessed centrally by a standardized 3-day dietary record. Urinary AER was determined in a central laboratory from a timed 24-h urine collection. Complete data were available from 2696 persons with IDDM from 30 centres in 16 European countries. In individuals who reported protein consumption less than $20 \%$ of total food energy intake, mean AER was below $20 \mu \mathrm{g} / \mathrm{min}$. In those in whom protein intake constituted more than $20 \%$, mean AER increased, a trend particularly pronounced in individuals with hypertension and/or poor metabolic control. Trends reached statistical significance for intakes of total protein $(\%$ of energy, $p=0.01)$ and animal protein ( $\%$ of energy, $p=0.02$ ), while no association was seen for vegetable protein $(p=0.83)$. These findings support the current recommendation for people with diabetes not to exceed a protein intake of $20 \%$ of total energy. Monitoring and adjustment of dietary protein appears particularly desirable for individuals with AER exceeding $20 \mu \mathrm{g} / \mathrm{min}$ (approximately $30 \mathrm{mg} / 24 \mathrm{~h}$ ), especially when arterial pressure is raised and/or diabetic control is poor. [Diabetologia (1997) 40: 1219-1226]

Keywords Insulin-dependent diabetes mellitus, protein intake, urinary albumin excretion rate, diabetic nephropathy, diet recommendations, Europe.
Kidney disease is a common and costly complication $[1,2]$ of diabetes mellitus, with individuals often requiring dialysis or renal transplantation. More than $30 \%$ of people with insulin-dependent diabetes

* see Acknowledgements for complete list of participating hospitals and clinics

Received: 11 April 1997 and in revised form: 10 June 1997

Corresponding author: Dr. M. Toeller, M.D., Diabetes Research Institute, Heinrich-Heine-University, Auf'm Hennekamp 65, D-40225 Düsseldorf, Germany

A bbreviations: IDDM, Insulin-dependent diabetes mellitus; AER, albumin excretion rate; DNSG, Diabetes and Nutrition Study Group; ADA, American Diabetes Association; CI, confidence interval. mellitus (IDDM) are at risk of manifest renal disease [3-5]. In the EURODIAB IDDM Complications Study $30.6 \%$ of a stratified European sample of individuals with IDDM aged 15-60 years (mean diabetes duration: 15 years) had albumin excretion rates (AER) of $20 \mu \mathrm{g} / \mathrm{min}$ or higher. In persons with a diabetes duration of $1-5$ years the rate of elevated AER was $19.3 \%$ [6]. This high prevalence of micro- and macroalbuminuria even early in IDDM and its predictive association for both clinical nephropathy [712] and increased cardiovascular disease risk [6, 1315] highlight the potential for early detection and effective prevention of diabetic vascular complications.

The use of low protein diets has been shown to reduce the progression of nephropathy in patients with clinically overt diabetic nephropathy [16-19]. In 
Table 1. Characteristics of IDDM patients

\begin{tabular}{llll}
\hline Characteristics & Total $(\mathrm{n}=2696)$ & Males $(\mathrm{n}=1364)$ & Females $(\mathrm{n}=1332)$ \\
\hline Age $($ years $)$ & $32.8 \pm 10.2$ & $32.8 \pm 10.2$ & $32.7 \pm 10.3$ \\
& $(14-61)$ & $(14-60)$ & $15-61)$ \\
Diabetes duration (years) & $14.7 \pm 9.3$ & $(1-5 \pm 9.3$ & $14.9 \pm 9.4$ \\
& $(1-56)$ & $23.5 \pm 2.7$ & $(1-47)$ \\
BMI $\left(\mathrm{kg} / \mathrm{m}^{2}\right)$ & $23.5 \pm 2.9$ & $(15-34)$ & $(15-39)$ \\
& $(15-39)$ & $6.3(6.2,6.5)$ & $6.4(6.3,6.5)$ \\
$\mathrm{HbA}_{1 \mathrm{c}}(\%)^{\mathrm{a}}$ & $6.4(6.3,6.4)$ & $18.4(17.0,20.0)$ & $15.0(13.9,16.1)$ \\
Albumin excretion rate $(\mu \mathrm{g} / \mathrm{min})^{\mathrm{a}}$ & $16.6(15.7,17.6)$ & $916(67.2)$ & $971(72.9)$ \\
AER $<20 \mu \mathrm{g} / \mathrm{min}(\mathrm{n}(\%))$ & $1887(70.0)$ & $320(23.5)$ & $259(19.4)$ \\
AER 20 to $200 \mu \mathrm{g} / \mathrm{min}(\mathrm{n}(\%))$ & $579(21.5)$ & $128(9.4)$ & $102(7.7)$ \\
AER $>200 \mu \mathrm{g} / \mathrm{min}(\mathrm{n}(\%))$ & $230(8.5)$ & $17.4 \pm 3.4$ & $1.53(1.51,1.56)$ \\
Total protein intake $(\%$ of energy) & $17.6 \pm 3.5$ & $12.0 \pm 3.6$ & $1.39(1.36,1.41)$ \\
$(\mathrm{g} / \mathrm{kg} \text { body weight })^{\mathrm{a}}$ & $1.46(1.44,1.48)$ & $5.2 \pm 1.3$ & $12.4 \pm 3.8$ \\
Animal protein intake $(\%$ of energy) & $12.2 \pm 3.7$ & $5.2 \pm 1.2$ \\
Vegetable protein intake $(\%$ of energy) & $5.2 \pm 1.3$ & \\
\hline
\end{tabular}

Data are mean \pm SD (range) or number of patients (\%).

${ }^{a}$ Geometric mean (95\% CI)

individuals with normo- and microalbuminuria restriction of protein intake has been found to reduce elevated glomerular filtration rate and albuminuria independently of control of blood glucose or blood pressure [20-24]. The level to which protein intake should be modified in order to achieve these beneficial effects has been examined in studies conducted in individuals with miro- $[21,25]$ and macroalbuminuria [16-19, 26]. However, a uniform therapeutic approach has not yet been established and the question as to whether even normoalbuminuric individuals with diabetes should decrease or modify their current protein intake to avoid the development of renal disease remains to be clarified $[27,28]$. The Diabetes and Nutrition Study Group of the European Association for the Study of Diabetes (EASD) [29] and the American Diabetes Association (ADA) [30] have recently recommended that protein intake in people with diabetes should range between 10 and $20 \%$ of total energy. For patients with incipient or manifest nephropathy a protein intake at the lower end of this range $(\cong$ $0.7-0.9 \mathrm{~g} / \mathrm{kg}$ body weight) is recommended [29].

The present paper aims to analyse the relationship between dietary protein intake and urinary AER in people with IDDM included in the cross-sectional, clinic-based EURODIAB IDDM Complications Study.

\section{Patients and methods}

Patients. The EURODIAB IDDM Complications Study was a cross-sectional clinic-based study in 31 European centres, designed to measure the prevalence of diabetic complications and to examine established and putative risk factors for these complications. Within each centre a stratified sample of up to 140 individuals with IDDM aged 15-60 years was selected. Stratification was based on sex, age and duration of diabetes; details of the selection procedure have already been published [31]. IDDM was defined as the onset of diabetes before the age of 36 years with continuous insulin treatment initiated within 1 year of diagnosis. Of the 3250 individuals with IDDM participating in the EURODIAB IDDM Complications Study a total of 2868 patients from 30 centres could be included in the nutritional analyses [32].

In the present analysis of the relation between dietary protein intake and urinary AER patients requiring dialysis $(n=11)$ were excluded. For 161 subjects no AER measurements were available. Therefore, data from 2696 persons (1364 males, 1332 females) were included in the present analysis of protein intake and AER. The characteristics are presented in Table 1.

The study conformed to the Declaration of Helsinki, and the study protocol was approved by local ethical committees in each centre. Informed consent was given by all individuals with IDDM.

M ethods. A standardized 3-day dietary record was employed for nutrition assessment. For this dietary method a good repeatability has already been documented [33]. The procedure used for nutrition assessment is described in detail elsewhere [32]. In brief, individuals were provided with instructions from their local dietitian on how to record all foods and beverages consumed over 3 days ( 2 workdays and a Sunday). A standardized list of food portion sizes and common household measures designed for this study was given to each person. The local centre dietitian carefully reviewed the completed 3day dietary record with each individual, in order to clearly identify and quantify all foods and beverages. Then the dietitian coded the food records using a centrally prepared EURODIAB food list. At the nutrition co-ordinating centre, food records were checked once again. Food records were then computer analysed using a nutrient database carefully compiled from a range of existing European food tables, with additional information from food companies. Dietary records were analysed for total protein, animal and vegetable protein, total fat, saturated fat and cholesterol, carbohydrate, fibre and alcohol. Total energy intake was calculated using Atwater factors [34].

The level of AER was measured in London (Guy's Hospital, Medical School) by an immunoturbidometric method 
(Sanofi, Pasteur, Minn., USA) from a timed 24-h urine collection. Samples with proteinuria due to urinary tract infections (Nephur-Test + Leuco, Boehringer, Mannheim, Germany) were excluded from analysis. AER was defined as normal below $20 \mu \mathrm{g} / \mathrm{min}$, as microalbuminuria at AER of 20 to $200 \mu \mathrm{g} /$ min, and macroalbuminuria for AER above $200 \mu \mathrm{g} / \mathrm{min}$.

$\mathrm{HbA}_{1 \mathrm{c}}$ values were determined in London (The Royal London Hospital) using an enzyme immunoassay with a notably low normal range of 2.9 to $4.8 \%$. Resting blood pressure was measured with a random zero sphygmomanometer. The mean of two readings to the nearest $2 \mathrm{mmHg}$ was used for analysis. Information as to whether persons were smokers (current or ex-) or non-smokers was available from a questionnaire completed by all individuals [35].

Statistical analysis. Mean daily intake of energy and nutrients was calculated from the 3-day record of each individual. The distributions of AER and $\mathrm{HbA}_{1 \mathrm{c}}$ as well as the dietary intake of energy, protein $/ \mathrm{kg}$ body weight, cholesterol $/ 1000 \mathrm{kcal}$ and fibre/1000 kcal were skewed. Thus, these variables were log transformed and geometric means were calculated.

The relationship between AER and protein is presented for all individuals and for groups stratified by glycaemic control or the presence of hypertension. For stratification by glycaemic control, the sample was divided in two groups, according to whether $\mathrm{HbA}_{1 \mathrm{c}}$ was below $6.4 \%$ (median $\mathrm{HbA}_{1 \mathrm{c}}$ value for the total study population) or greater. The presence of hypertension was defined as a blood pressure of $140 / 90 \mathrm{mmHg}$ or above and/or taking blood pressure lowering drugs.

Protein intake was treated as a series of dummy variables, where a separate variable was assigned for each level of protein intake ( $\leq 12 \%, 12-14 \%$... to $>24 \%$ ). Mean AER calculated for each level of protein intake was adjusted for age, diabetes duration and total energy intake employing the multivariate nutrient density model [36]. In this least square regression model protein intake is expressed as nutrient density and entered in the model simultaneously with total energy intake. The adjusted means were the values predicted by the model when the other variables were held at their mean values. Furthermore, a test for interaction was carried out to investigate whether the relationship between protein intake and AER differed between the defined strata.

Statistical significances in the relationship between protein intake and AER were determined by a trend analysis using the multivariate nutrient density model adjusting for total energy intake. In a further step, other parameters possibly related to the development of early nephropathy (age, diabetes duration, $\mathrm{HbA}_{1 \mathrm{c}}$, diastolic blood pressure and smoking) were entered in the model. Due to missing data only 1998 individuals (1011 males, 987 females) could be included in the models when adjusting for centrally measured $\mathrm{HbA}_{1 \mathrm{c}}$ concentrations.

Comparison of protein intakes between patients with micro- or macroalbuminuria and subjects with normoalbuminuria was carried out calculating adjusted nutrient intakes separately for each group and testing for differences using intakes in normoalbuminuric individuals as the reference category. Since the distribution of alcohol intake was highly skewed in place of geometric means adjusted percentages of alcohol consumers are given for the groups of persons with normo-, microand macroalbuminuria.

All statistical analyses were carried out using the SAS program [37].

\section{Results}

Mean protein intake and mean AER for the 2696 individuals with IDDM are given in Table 1 . Protein intakes above the recommended upper level of $20 \%$ of energy were found in $22 \%$ of the persons with diabetes $(n=601)$. Of the patients with macroalbuminuria $32 \%$ consumed more than $20 \%$ of protein, while this percentage was $23 \%$ for the micro- and $20 \%$ for the normoalbuminuric individuals with IDDM.

The relation between protein intake and AER for all individuals is illustrated in Figure 1 (top). In categories of persons with protein intakes below $20 \%$ of energy mean AER remained at levels of 13.5 to $16.6 \mu \mathrm{g} / \mathrm{min}$, thereafter approaching mean AER values of 18.9 to $23.6 \mu \mathrm{g} / \mathrm{min}$ in categories of individuals consuming more than $20 \%$ of protein. Figure 1 (middle) compares the relation of protein intake with AER between the two strata of glycaemic control. Overall, mean AER was increased in subjects with a higher $\mathrm{HbA}_{1 \mathrm{c}}$ (range of mean AER: 6.7 to $33.4 \mu \mathrm{g} /$ min) as compared to individuals with lower $\mathrm{HbA}_{1 \mathrm{c}}$ values (range of mean AER: 11.7 to $16.5 \mu \mathrm{g} / \mathrm{min}$ ). The trend of AER to rise in categories with protein intakes above $20 \%$ could be found for the strata of persons with a higher $\mathrm{HbA}_{1 \mathrm{c}}$, while this association was not observed for the stratum of individuals with $\mathrm{HbA}_{1 \mathrm{c}}$ below $6.4 \%$ (test for interaction between strata, $p=0.03$ ). The lowest panel of Figure 1 illustrates that subjects with hypertension generally had a higher AER (range of mean AER: 27.7 to $86.8 \mu \mathrm{g} / \mathrm{min}$ ) as compared to normotensive individuals (range of mean AER: 9.1 to $17.7 \mu \mathrm{g} / \mathrm{min}$ ). A notable increase in mean AER was seen for hypertensive patients with protein intakes above $20 \%$, while this trend was not pronounced in the stratum of subjects without hypertension (test for interaction between strata, $p=0.0001)$.

Figure 2 illustrates that adjusted mean AER was appreciably greater when protein provided more than $20 \%$ of energy as compared to the mean AER in patients consuming up to $20 \%$ of protein. This tendency was most pronounced in patients with hypertension or in those with both hypertension and poor diabetes control. Hypertension was not found to be more frequent in patients with a high protein intake.

The test for a linear relationship between protein intake and AER revealed a significant trend of energy adjusted AER to rise with higher intakes of total protein ( $\%$ of energy, $\beta=0.02$ [CI 0.01, 0.04], $\mathrm{p}=0.01$ ) or animal protein (\% of energy, $\beta=0.02$ [CI 0.003, 0.03], $p=0.02$ ), while trends were not significant for vegetable protein (\% of energy, $\beta=0.01$ $[\mathrm{CI}-0.04,0.05], \mathrm{p}=0.83$ ) or protein related to body weight $(\mathrm{g} / \mathrm{kg}$ body weight, $\beta=0.1$ [CI $-0.1,0.3$ ], $p=0.38$ ). After inclusion of diabetes duration, age, $\mathrm{HbA}_{1 \mathrm{c}}$, diastolic blood pressure (mean $\pm \mathrm{SD}$ : 

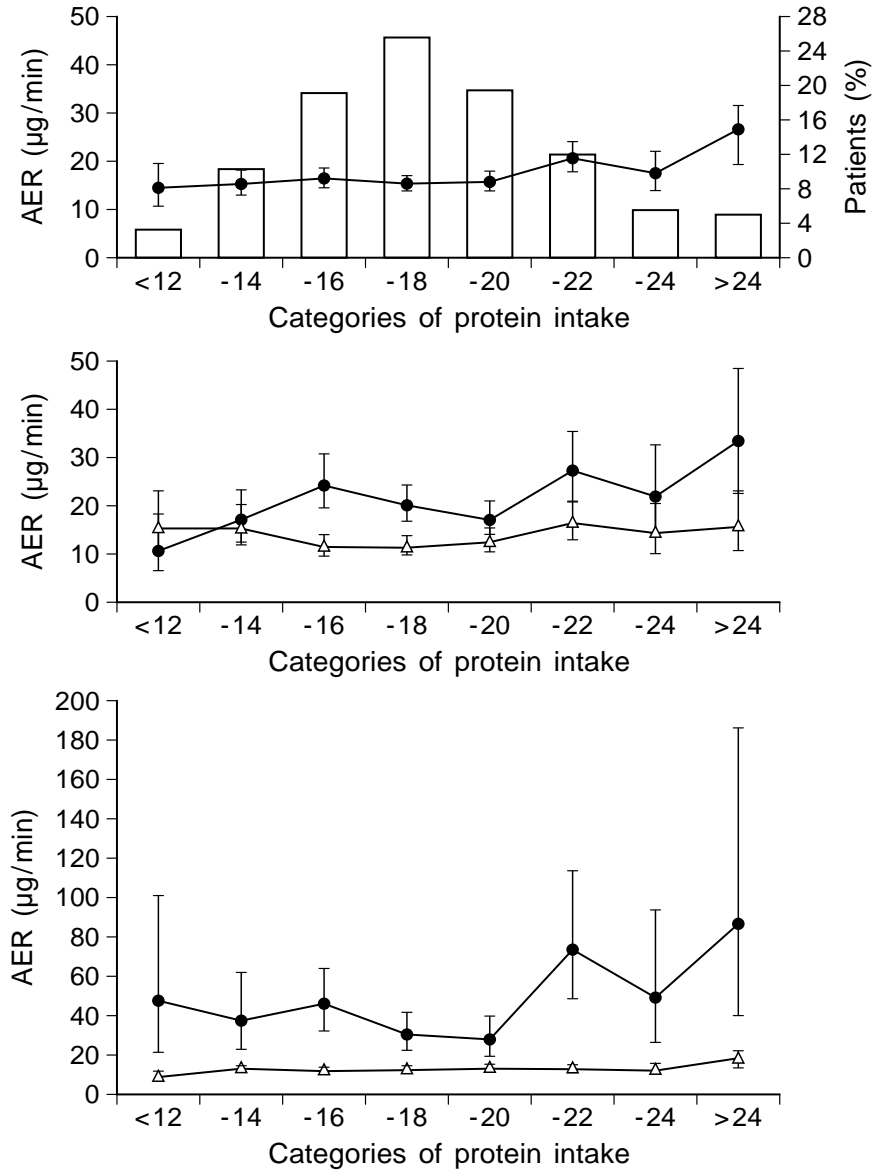

Fig. 1. Top: Geometric mean AER (- - ) for different categories of protein intake $(\leq 12 \% \ldots>24 \%$ of total food energy) in 2696 individuals with IDDM. Columns indicate percentage of individuals with IDDM in different categories of protein intake. M iddle: Geometric mean AER in 999 individuals with $\mathrm{HbA}_{1 \mathrm{c}}<6.4 \% \quad(-\Delta-)$ compared to 1007 subjects with $\mathrm{HbA}_{1 \mathrm{c}} \geq 6.4 \%$ (一). Bottom: Geometric mean AER in 2050 normotensive individuals $(-\Delta-)$ compared to 619 hypertensive patients (- - . All geometric means with $95 \%$ confidence intervals $(\perp)$ are adjusted for total energy intake, age, and diabetes duration

$75.4 \pm 11.3 \mathrm{mmHg})$ and smoking $(50 \%$ were current or ex-smokers) in the model, the trends observed for total protein and animal protein remained significant $(\beta=0.03$ [CI 0.01, 0.05], $\mathrm{p}=0.001$ and $\beta=0.02$ [CI $0.01,0.04], \quad p=0.01$, respectively). Furthermore, AER adjusted for these confounding factors was significantly associated with protein intakes related to body weight $(\beta=0.25$ [CI $0.01,0.5], \mathrm{p}=0.045)$, while a positive relationship with vegetable protein could not be established $(\beta=0.032$ [CI $-0.02,0.08$, $\mathrm{p}=0.25$ ).

In Table 2 nutritional intakes of individuals with macro- and microalbuminuria are compared with intakes of persons with normoalbuminuria. Nutritional intakes were also adjusted for age, diabetes duration, $\mathrm{HbA}_{1 \mathrm{c}}$, diastolic blood pressure and smoking, variables which were all found to be

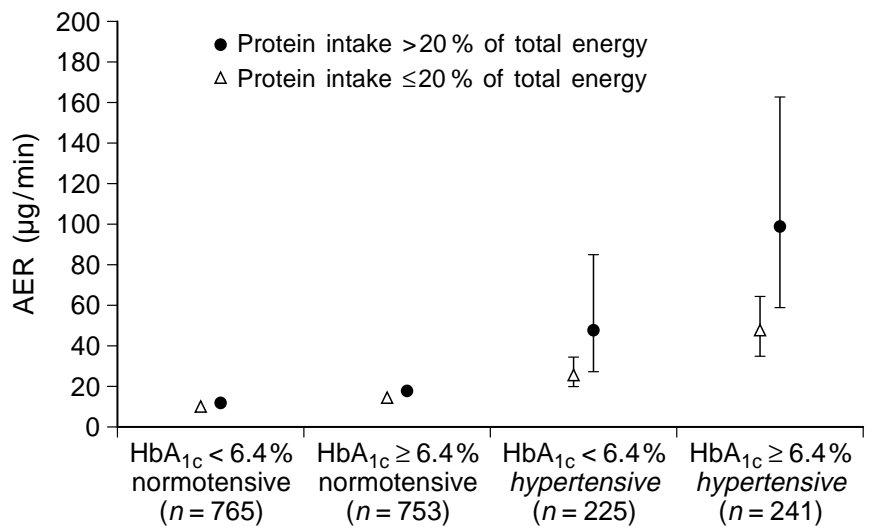

Fig. 2. Geometric mean AER in individuals with protein intakes up to $20 \%$ of total energy $(\triangle)$ compared to subjects consuming more than $20 \%$ of protein (O): by strata of glycaemic control and presence of hypertension. The geometric means with $95 \%$ confidence intervals $(\mid)$ are adjusted for total energy intake, age, and diabetes duration

significantly increased in subjects with macro- and microalbuminuria as compared to patients with normoalbuminuria. Patients with macroalbuminuria consumed significantly more total protein, animal protein and $\mathrm{g}$ protein per $\mathrm{kg}$ body weight than normoalbuminuric individuals. Non-significant trends in the same direction were found between subjects with microalbuminuria and those with normoalbuminuria.

Findings were similar whether the relationship between protein intake and AER was analysed adjusting for systolic blood pressure or for diastolic pressure. Addition of a term for height, BMI or blood lipids did not account for the correlation between protein intake and AER (data not shown).

\section{Discussion}

Dietary protein intake may influence renal disease in individuals with diabetes [38]. Therefore, the present study analysed the relationship between reported dietary protein intake and urinary AER in 2696 IDDM individuals from the EURODIAB Complications Study. The dietary intake of protein expressed as a percentage of total food energy intake was found to be related to urinary AER. For persons with protein intakes up to $20 \%$, mean AER did not exceed the upper level of normoalbuminuria, while elevated mean AER levels were observed in individuals with a protein consumption above $20 \%$ of food energy intake. Protein intakes at the lower end of the recommended range were not associated with lower AER values; but few subjects had a protein consumption below $12 \%$ of energy, some of whom may have followed advice to 
Table 2. Nutritional intake in IDDM patients with normo-, micro- and macroalbuminuria

\begin{tabular}{lccc}
\hline Nutritional intake & $\begin{array}{l}\text { AER }<20 \mu \mathrm{g} / \mathrm{min} \\
(\mathrm{n}=1887)\end{array}$ & $\begin{array}{l}\text { AER 20-200 } \mu \mathrm{g} / \mathrm{min} \\
(\mathrm{n}=579)\end{array}$ & $\begin{array}{l}\text { AER }>200 \mu \mathrm{g} / \mathrm{min} \\
(\mathrm{n}=230)\end{array}$ \\
\hline Total protein (\% of energy) & $17.6(17.4,17.8)$ & $17.8(17.5,18.1)$ & $18.5(18.0,19.0)^{\mathrm{a}}$ \\
Animal protein (\% of energy) & $12.2(12.0,12.4)$ & $12.5(12.2,12.8)$ & $12.9(12.4,13.5)^{\mathrm{a}}$ \\
Vegetable protein (\% of energy) & $5.2(5.1,5.2)$ & $5.1(5.0,5.3)$ & $5.3(5.1,5.5)$ \\
g Protein/kg body weight & $1.46(1.44,1.48)$ & $1.46(1.42,1.50)$ & $1.52(1.47,1.59)^{\mathrm{a}}$ \\
Fat (\% of energy) & $37.8(37.4,38.2)$ & $38.4(37.7,39.0)$ & $36.7(35.6,37.8)$ \\
Saturated fatty acids (\% of energy) & $13.8(13.6,13.9)$ & $13.8(13.5,14.2)$ & $13.0(12.5,13.6)^{\mathrm{a}}$ \\
Cholesterol (mg/1000 kcal) & $141(138,144)$ & $144(138,150)$ & $151(141,161)$ \\
Carbohydrate (\% of energy) & $42.5(42.1,42.9)$ & $41.5(40.8,42.2)^{\mathrm{a}}$ & $73.1(42.0,44.2)$ \\
Fibre (g/1000 kcal) & $7.4(7.3,7.6)$ & $7.1(6.8,7.4)^{\mathrm{a}}$ & $7.5(7.1,7.9)$ \\
Energy (kcal) & $2270(2235,2306)$ & $2331(2264,2399)$ & $2250(2148,2356)$ \\
Alcohol consumers (\% of patients & $49.1(46.4,51.7)$ & $54.6(49.9,53.4)^{\mathrm{a}}$ & $44.5(36.8,52.1)$
\end{tabular}

recording alcohol intake over 3-days)

Data are geometric means (95\% CI).

Energy intakes are adjusted for age, duration, $\mathrm{HbA}_{1 \mathrm{c}}$, diastolic blood pressure and smoking.

reduce their protein intake because of high levels of AER.

Other smaller cross-sectional epidemiological studies in people with both insulin- and non-insulindependent diabetes have not found associations between protein intake with urinary AER [39, 40] or with the presence of clinical proteinuria [41]. Our contrasting results may be partly attributable to the size and structuring of the EURODIAB IDDM Complications Study. Furthermore, most studies investigating the role of protein intake as a risk factor for renal disease did not allow for total energy intake. Despite the fact that correct adjustment for total energy intake in epidemiological analyses of dietary data is increasingly recognised as an important aspect of the interpretation of nutritional studies $[36,42]$ the concept of energy adjustment has not yet been widely adopted.

High intakes of protein require increased renal excretory function and are associated with higher glomerular filtration rates [16, 25, 43, 44]. High protein intakes are therefore postulated as determinants of the deterioration of clinically overt diabetic nephropathy [26] and perhaps of the progression from stages of diabetic nephropathy without clinical signs to incipient diabetic nephropathy $[28,44]$. However, a clear level of undesirably high protein intake has not been established for persons with diabetes. The Diabetes and Nutrition Study Group of the EASD and the ADA have chosen an upper limit of $20 \%$ of energy intake for protein in their nutritional recommendations $[29,30]$, a level considered to be the upper limit of protein consumption commonly observed in the general population [30]. This recommendation finds some support in our finding that protein intakes above $20 \%$ are associated with elevated levels of AER in European individuals with IDDM.
Nutrient intakes and percentages of alcohol consumers are adjusted for energy, age, duration, $\mathrm{HbA}_{1 \mathrm{c}}$, diastolic blood pressure and smoking.

${ }^{a}$ Intakes significantly different from intakes in patients with normoalbuminuria, $\mathrm{p}<0.05$

Diabetic patients with incipient or manifest nephropathy (i.e. presence of micro- or macroalbuminuria [45]) are recommended to reduce their protein intake to $0.7-0.9 \mathrm{~g} / \mathrm{kg}$ body weight (approximately $10 \%$ of food energy) [29]. However, in the present study individuals with micro- or macroalbuminuria were found to consume even more total protein and animal protein than persons with normoalbuminuria. Other studies reported that in comparison to individuals with normoalbuminuria, protein intakes found in patients with micro- or macroalbuminuria were similarly high $[46,47]$.

Current therapeutic approaches focus primarily on optimisation of blood pressure and glycaemic control. For these factors clear associations with the progression of nephropathy have already been shown $[4,5,8,39,48-55]$. Reduction of dietary protein is considered only when renal function is reduced and declining. In the present study we observed that AER was strongly associated with the presence of hypertension or higher $\mathrm{HbA}_{1 \mathrm{c}}$ values, while a weaker relationship was seen with dietary intake of protein. The association between higher AER and higher dietary protein intake that we demonstrated was of particular importance for patients with hypertension and/or higher $\mathrm{HbA}_{1 \mathrm{c}}$ values, with the presence of hypertension having a greater impact than that of a poorer diabetes control.

The statistically significant relationship between intakes of total protein and AER was observed for animal protein, but not for vegetable protein, a finding which supports other evidence of the specially deleterious effect on renal function of animal protein $[21,24,27,56]$. Since long-term compliance to low-protein diets is often poor [21, 22] a modification of protein intake $[22,25,27,28,56,57]$, substituting vegetable protein for protein from animal sources, should be more fully explored as a feasible 
therapeutic approach which would also reduce total fat and saturated fatty acid consumption. While high protein intakes were a unanimous finding in all EURODIAB centres [32] the pattern of food groups providing protein/animal protein may vary considerably across European countries. It may be that specific components of animal protein (e.g. meat) exert particularly deleterious effects. Further detailed analyses of the food intake reported by the EURODIAB cohort might help to clarify these important issues.

In conclusion the present study demonstrates a significant relationship between dietary protein intake and urinary AER in European individuals with IDDM. This is largely restricted to those consuming more than $20 \%$ of their dietary food energy as protein, particularly perhaps if this is of animal origin. Our data provide some support for current nutritional recommendations for people with IDDM not to exceed a protein intake of $20 \%$. In diabetic persons whose urinary AER falls into the micro- or macroalbuminuric range more attention should be directed towards the avoidance of protein intakes higher than $20 \%$ of total energy, particularly in the presence of elevated blood pressure and/or poor glycaemic control, both of which require corrective action in their own right.

A cknowledgements. The participation of the patients in the study is gratefully acknowledged. We thank all dietitians and nutritionists in the EURODIAB centres for their excellent co-operation. The study was part of the EURODIAB Concerted Action Programme financially supported by the Commission of the European Community. Additional financial support was received from the research funds of the Nutrition Co-ordinating Centre at the Diabetes Research Institute in Düsseldorf to analyse the nutritional data.

We would also like to express our gratitude to the statistician L. Stevens from the University College London, Department of Epidemiology and Public Health for her helpful statistical advice.

E URODIA B Steering Committee M embers: J.H. Fuller (London), H. Keen, Chairman (London), H. M. J. Krans (Leiden), R. Navalesi (Pisa), A.-K. Sjolie (Aarhus), J.M. Stephenson (London), M. Toeller (Düsseldorf), G.-C. Viberti (London), J. Ward (Sheffield).

D ata Co-ordinating Centre: J.H. Fuller, University College London, Department of Epidemiology and Public Health, London, UK.

Nutrition C o-ordinating Centre: M. Toeller, Diabetes Research Institute, Heinrich-Heine-University, Düsseldorf, Germany.

Central L aboratories: G. John, The Royal London Hospital, and G.-C. Viberti, M. Mattock, A. Collins, A. Dredge, R. Sharp, Guy's Hospital, London, UK.

EURODIAB Centres and I nvestigators

B. Karamanos, C. Tountas, A. Kofinis, K. Petrou, N. Katsilambros, D. Roussi-Penessi, Hippokration Hospital, Athens, Greece
M. Cignarelli, R. Giorgino, M. L. De Geco, I. Ramunni, Cattedra di Endocrinologia-Policlinico, Bari, Italy

C. Ionescu-Tirgoviste, R. Strachinariu, A. Nicolau, Clinic of Diabetes, Nutrition and Metabolic Diseases, Bucharest, Rumania G. Tamas, Z. Kerenyi, A. M. Ahmed, J. Toth, P. Kempler, Tetenyi Teaching Hospital and Semmelweis University, Budapest, Hungary

S. Muntoni, M. Songini, M. Stabilini, M. Fossarello, S. Pintus, Ospedale San Michele, Cagliari, Italy

B. Ferriss, C. C. Cronin, M. Humphreys, Cork Regional Hospital, Ireland

M. Toeller, A. Klischan, T. Forst, F. A. Gries, W. Schumacher, Diabetes-Forschungsinstitut, Universität Düsseldorf, Germany

R. Rottiers, H. Priem, M. J. Deschoolmeester, University Hospital of Gent, Belgium

P. Ebeling, M. Sinisalo, V.A. Koivisto, University Hospital of Helsinki, Finland

B. Idzior-Walus, B. Solnica, L. Szopinska-Ciba, K. Solnica, University School of Medicine, Krakow, Poland

H.M.J. Krans, H. H. P. J. Lemkes, J. J. Jansen, B. M. Elte-de Wever, University Hospital of Leiden, The Netherlands

J. Nunes-Correa, J. Boavida, R. Carvalho, M. J. Afonso, M. Monteiro, R. David, Portuguese Diabetic Association, Lisbon, Portugal

E. Jepson, S. McHardy-Young, Central Middlesex Hospital, and J.H. Fuller, D. J. Betteridge, M. Milne, T. Thompson, University College Hospital, NW London, UK

G. Michel, R. Wirion, S. Paquet, H. Hornick, Centre Hospitalier, Luxembourg

A.J.M. Boulton, H. Ashe, D.J.S. Fernando, J. Curwell, Manchester Royal Infirmary, UK

G. Pozza, G. Slaviero, G. Comi, B. Fattor, F. Bandello, M. Marchi, Ospedale San Raffaele, Milan, Italy

H. Mehnert, A. Nuber, H. Janka, M. Nichting, E. Standl, City Hospital Schwabing, Munich, Germany

G. Crepaldi, R. Nosadini, Istituto di Medicina Interna, University of Padua, Italy

G. Cathelineau, B. Villatte Cathelineau, M. Jellal, N. Grodner, P. Gervais Feiss, N. Baclet, Hospital Saint-Louis, Paris, France

F. Santeusanio, G. Rosi, M. R. M. Ventura, C. Cagini, C. Marino, Instituto di Patologia Medica, Policlinico, Perugia, Italy

R. Navalesi, G. Penno, R. Miccoli, M. Nannipieri, S. Manfredi, A. Bertolotto, Instituto di Clinica Medica II, Pisa, Italy

G. Ghirlanda, P. Cotroneo, A. Manto, C. Teodonio, A. Minnella, G. Careddu, Universita Cattolica del Sacro Cuore, Rome, Italy

J.D. Ward, S. Tesfaye, C. Mody, C. Rudd, Royal Hallamshire Hospital, Sheffield, UK

G.M. Molinatti, F. Vitelli, M. Porta, G. F. Pagano, P. Estivi, R. Sivieri, Q. Carta, G. Petraroli, Clinica Medica B, Patologia Medica, Ospedale Molinette, and Ospedale "Agnelli", Turin, Italy

N. Papazoglou, M. Goutzourela, C. Manes, General Hospital of Thessaloniki, Greece

D. Ben Soussan, M.-C. Fallas, P. Fallas, C. Dhanaeus, M.D. Bourgeois, Centre Hospitalier de Valenciennes, France M. Muggeo, V. Cacciatori, F. Bellavere, P. Galante, M. L. Gemma, P. Branzi, Cattedra di Malattie del Metabolismo, Verona, Italy

K. Irsigler, H. Abrahamian, C. Gurdet, B. Hornlein, C. Willinger, H. Strohner, M. Just, Hospital Vienna Lainz, Austria S. Walford, E. V. Wardle, S. Henio, H. Cooke, New Cross Hospital, Wolverhampton, UK

G. Roglic, Z. Resman, Z. Metelko, Z. Skrabalo, Vuk Vrhovac Institute for Diabetes, Zagreb, Croatia 


\section{References}

1. Hull AR (1992) Impact of reimbursement regulations on patient management. Am J Kidney Dis 20 [Suppl. 1]:8-11

2. Borch-Johnsen K, Wenzel H, Viberti GC, Mogensen CE (1993) Is screening and intervention for microalbuminuria worthwhile in patients with insulin dependent diabetes? BMJ 306: 1722-1725

3. Andersen AR, Christiansen JS, Andersen JK, Kreiner S, Deckert T (1983) Diabetic nephropathy in type 1 (insulindependent) diabetes: an epidemiological study. Diabetologia 25: 496-501

4. Borch-Johnsen K (1989) The prognosis of insulin-dependent diabetes mellitus. An epidemiological approach. Danish Medical Bulletin 36: 336-348

5. Krolewski AS, Warram JH, Christlieb AR, Busick EJ, Kahn CR (1985) The changing natural history of nephropathy in type I diabetes. Am J Med 78: 785-794

6. Stephenson JM, Fuller JH and the EURODIAB IDDM Complications Study (1994) Microalbuminuria is not rare before 5 years of IDDM. J Diab Compl 8: 166-173

7. Messent JWC, Elliott TG, Hill RD, Jarrett RJ, Keen H, Viberti GC (1992) Prognostic significance of microalbuminuria in insulin-dependent diabetes mellitus: a twenty-three year follow-up study. Kid Int 41: 836-839

8. Mogensen CE (1984) Predicting diabetic nephropathy in insulin dependent patients. N Engl J Med 311: 89-93

9. Mogensen CE, Chachati A, Christensen CK et al. (1986) Microalbuminuria: an early marker of renal involvement in diabetes. Uremia Invest 9: 86-95

10. Viberti GC, Hill RD, Jarrett RJ, Argyropoulos A, Mahmud U, Keen H (1982) Microalbuminuria as a predictor of clinical nephropathy in insulin dependent diabetes mellitus. Lancet 1: 1430-1432

11. Parving H-H, Oxenboll B, Svendsen PA, Christiansen JS, Andersen AR (1982) Early detection of patients at risk of developing diabetic nephropathy: A longitudinal study of urinary albumin excretion. Acta Endocrinol 100: 550-555

12. Borch-Johnsen K, Kreiner S (1987) Proteinuria: Value as a predictor of cardiovascular mortality in insulin dependent diabetes mellitus. BMJ 294: 1651-1654

13. Deckert T, Yokoyama H, Mathiesen E et al. (1996) Cohort study of predictive value of urinary albumin excretion for atherosclerotic vascular disease in patients with insulin-dependent diabetes. BMJ 312: 871-874

14. Groop PH, Viberti GC, Elliott TG et al. (1994) Lipoprotein(a) in type 1 diabetic patients with renal disease. Diabet Med 11: 961-967

15. Torffvit O, Agardh C-D (1993) The predictive value of albuminuria for cardiovascular and renal disease. A 5-year follow-up study of 476 patients with type I diabetes mellitus. J Diab Comp 7: 49-56

16. Zeller K, Whittaker E, Sullivan L, Raskin P, Jacobson HR (1991) Effect of restricting dietary protein on the progression of renal failure in patients with insulin dependent diabetes mellitus. N Engl J Med 324: 78-84

17. Brouhard BH, LaGrone L (1990) Effect of dietary protein restriction on functional renal reserve in diabetic nephropathy. Am J Med 89: 427-431

18. Evanoff GV, Thompson CS, Brown J, Weinman EJ (1987) The effect of dietary protein restriction on the progression of diabetic nephropathy. A 12-month follow-up. Arch Intern Med 147: 492-495

19. Walker JD, Bending JJ, Dodds RA et al. (1989) Restriction of dietary protein and progression of renal failure in diabetic nephropathy. Lancet 2: 1411-1415
20. Cohen DL, Dodds R, Viberti GC (1987) Effect of protein restriction in insulin-dependent diabetics at risk of nephropathy. Br J Med 294: 795-798

21. Dullaart RP, Beusekamp BJ, Meijer S, van Doormaal JJ, Sluiter WJ (1993) Long-term effects of protein-restricted diet on albuminuria and renal function in IDDM patients without clinical nephropathy and hypertension. Diabetes Care 16: 483-492

22. Percheron C, Colette C, Astre C, Monnier L (1995) Effects of moderate changes in protein intake on urinary albumin excretion in type I diabetic patients. Nutrition 11: 345-349

23. Wiseman MJ, Bognetti E, Dodds R, Keen H, Viberti GC (1987) Changes in renal function in response to protein restricted diet in type 1 (insulin-dependent) diabetic patients. Diabetologia 30: 154-159

24. Viberti GC (1988) Low protein diet and progression of diabetic kidney disease. Nephrol Dial Transplant 3: 334-339

25. Kupin W, Cortes P, Dumler F, Feldkamp CS, Kilates MC, Levin NW (1987) Effect on renal function of change from high to moderate protein intake in type I diabetic patients. Diabetes 36: 73-79

26. Raal FJ, Kalk WJ, Lawson M, Esser JD, Buys R, Fourie L, Panz VR (1994) Effect of moderate dietary protein restriction on the progression of overt diabetic nephropathy: a 6 mo prospective study. Am J Clin Nutr 60: 579-585

27. Kontessis PS, Bossinakaou I, Sarika L et al. (1995) Renal, metabolic and hormonal responses to proteins of different origin in normotensive, nonproteinuric type I diabetic patients. Diabetes Care 18: 1233-1240

28. Pedersen MM, Mogensen CE, Jorgensen FS, Moller B, Lykke G, Pedersen O (1989) Renal effects from limitation of high dietary protein in normoalbuminuric diabetic patients. Kidney Int 27 [Suppl]:115S-121S

29. Diabetes Nutrition Study Group of the European Association for the Study of Diabetes (1995) Recommendations for the nutritional management of patients with diabetes mellitus. Diab Nutr Metab 8: 186-189

30. American Diabetes Association (1994) Nutrition recommendations and principles for people with diabetes mellitus. Diabetes Care 17: 519-522

31. The EURODIAB IDDM Complications Study Group (1994) Microvascular and acute complications in IDDM patients: the EURODIAB IDDM Complications Study. Diabetologia 37: 278-285

32. Toeller M, Klischan A, Heitkamp G et al. and the EURODIAB IDDM Complications Study (1996) Nutritional intake of 2868 IDDM patients from 30 centres in Europe. Diabetologia 39: 929-939

33. Toeller M, Buyken A, Heitkamp G, Milne R, Klischan A, Gries FA and the EURODIAB IDDM Complications Study (1997) Repeatability of three-day dietary records in the EURODIAB IDDM Complications Study. Eur J Clin Nutr 51: 74-80

34. Atwater WO, Bryant AP (1900) The availability and fuel value of food materials. Report of the Storrs Agricultural Experimental Station 1899: 73-110

35. Chaturvedi N, Stevenson JM, Fuller JH (1995) The relationship between smoking and microvascular complications in the EURODIAB IDDM complications study. Diabetes Care 18: 785-792

36. Willett W (1990) Implications of total energy intake for epidemiologic analyses. In: B Mac Mahon (ed) Nutritional epidemiology. Oxford University Press, New York, Oxford pp 245-271

37. SAS Institute (1995) SAS for Windows Version 6.11. SAS Institute Inc. Cary (NC) USA 
38. WHO Study Group (1994) Prevention of diabetes mellitus. World Health Organisation Technical Report Series 844

39. Kalk WJ, Osler C, Constable J, Kruger M, Panz V (1992) Influence of dietary protein on glomerular filtration and urinary albumin excretion in insulin dependent diabetes. Am J Clin Nutr 56: 169-173

40. Summerson JH, Bell RA, Konen JC (1996) Dietary protein intake, clinical proteinuria, and microalbuminuria in non-insulin-dependent diabetes mellitus. J Ren Nutr 6: 89-93

41. Jameel N, Pugh JA, Mitchell BD, Stern MP (1992) Dietary protein intake is not correlated with clinical proteinuria in NIDDM. Diabetes Care 15: 178-183

42. Martin-Moreno JM (1993) Adjustment for total caloric intake in nutritional studies: an epidemiological perspective. Eur J Clin Nutr 47 [Suppl 2]:51S-52S

43. Fioretto P, Trevisan R, Giorato C et al. (1988) Type I insulin-dependent diabetic patients show an impaired renal hemodynamic response to protein intake. J Diabetic Complic 2: 27-29

44. Jones SL, Kontessis P, Wiseman M et al. (1992) Protein intake and blood glucose as modulators of GFR in hyperfiltering diabetic patients. Kidney Int 41: 1620-1628

45. Mogensen CE, Christensen CK, Vittinghus E (1983) The stages in diabetic renal disease with emphasis on the stage of incipient diabetic nephropathy. Diabetes 32 [Suppl 2]:64-78

46. Nyberg G, Norden G, Attman PO, Aurell M, Uddebom G, Lenner RA, Isaksson B (1987) Diabetic nephropathy: is dietary protein harmful? J Diab Compl 1: 37-40

47. Watts GF, Gregory L, Naoumova R, Kubal C, Shaw KM (1988) Nutrient intake in insulin dependent diabetic patients with incipient nephropathy. Eur J Clin Nutr 42: 697702

48. Mathiesen ER, Ronn B, Jensen T, Storm B, Deckert T (1990) Relationship between blood pressure and urinary albumin excretion in development of microalbuminuria. Diabetes 39: 245-249

49. The Diabetes Control and Complications Trial Research Group (1993) The effect of intensive treatment of diabetes on the development and progresssion of long-term complications in insulin-dependent diabetes mellitus. $\mathrm{N}$ Engl J Med 329: 977-986

50. Feldt-Rasmussen B, Mathiesen ER, Deckert T (1986) Effect of two years of strict metabolic control on progression of incipient nephropathy in insulin-dependent diabetes. Lancet II:1300-1304

51. Bojestig M, Arnqvist HJ, Karlberg BE, Ludvigsson J (1996) Glycaemic control and prognosis in type I diabetic patients with microalbuminuria. Diabetes Care 19: 313-317

52. Wiseman M, Viberti G, Mackintosh D, Jarrett RJ, Keen H (1984) Glycaemia, arterial pressure and microalbuminuria in type 1 (insulin-dependent) diabetes mellitus. Diabetologia 26: 401-405

53. Coonrod BA, Ellis D, Becker DJ et al. (1993) Predictors of microalbuminuria in individuals with IDDM. Pittsburgh Epidemiology of Diabetes Complications Study. Diabetes Care 16: 1376-1383

54. Vestbo E, Damsgaard EM, Froland A, Mogensen CE (1995) Urinary albumin excretion in a population based cohort. Diabet Med 12: 488-493

55. Manto A, Cotroneo P, Marra G, Magnani P, Tilli P, Greco AV, Ghirlanda G (1995) Effect of intensive treatment on diabetic nephropathy in patients with type I diabetes. Kid Int 47: 231-235

56. Jibani MM, Bloodworth LL, Foden E, Griffiths KD, Galpin OP (1991) Predominantly vegetarian diet in patients with incipient and early clinical diabetic nephropathy: effects on albumin excretion rate and nutritional status. Diabet Med 8: 949-953

57. Henry RR (1994) Protein content of the diabetic diet. Diabetes Care 17: 1502-1513 